Всеукраїнської наук.-практ. конф. (Харків, 14-16 травня 2007 р.)]. - Харків, 2007. - С. 61-65. 7. Сікорський П. Принципи моделювання оцінювальних систем / Петро Сікорський, Ольга Біляковська // Шлях освіти. - 2006. - № 1. - С. 14-17. 8. Сікорський П. Моделювання дидактичних систем оцінювання / Петро Сікорський, Ольга Біляковська // Шлях освіти. - 2006. № 2. - С. 2-6. 9. Харитонова И. В. Рейтинговая система контроля математических знаний студентов : дис. ... канд. пед. наук : 13.00.02. / Харитонова Ирина Владимировна. - Москва, 2003. $-185 \mathrm{c}$.

УДК 378.147:004

С. М. Грищенко,

здобувач,

ДВНЗ «Криворізький наиіональний університет»

\title{
ФОРМУВАННЯ ТВОРЧОГО ПІДХОДУ ДО НАВЧАННЯ
}

Грищенко С. М. Формування творчого підходу до навчання.

У статті висвітлюється проблема формування творчого підходу викладача до організації навчального процесу і творчого ставлення студентів до навчання в предметно-орієнтованому комп'ютерному середовищі.

Ключові слова: творчість, предметно-орієнтоване комп'ютерне середовище, інформаційні технології, навчально-рольова гра.

Грищенко С. М. Формирование творческого подхода к обучению.

В статье освещается проблема формирования творческого подхода преподавателя к организации учебного процесса и творческого отношения студентов к обучению в предметноориентированной компьютерной среде.

Ключевые слова: творчество, предметно-ориентированная компьютерная среда, информационные технологии, учебно-ролевая игра.

Grischenko S. M. Forming creative approach to teaching.

The article highlights the problem of the creative teacher to the educational process and creative approach to teaching students in object-oriented computing environment.

Key words: creativity, object-oriented computing environment, information technology, training and role-playing game.

Інтенсивний розвиток інформаційних технологій вимагає більш високого наукового, технологічного й гуманітарного рівня підготовки фахівців. Виникає потреба у фахівцях, що володіють системою наукових знань, уміннями і навичками самостійної роботи, творчим ставленням до навчання і праці.

У суспільному житті часто виникають проблемні ситуації, для розв’язання яких слід застосовувати знання та вміння, накопичені у процесі навчання. Однак пропонована для засвоєння навчальна інформація становить систему абстрактних, формальних відомостей (у вигляді тексту, моделей, знакових систем), які рідко можна використати на практиці в чистому вигляді. Отже, в освітньому процесі необхідно акцентувати увагу на формуванні у студентів навичок здійснювати перенесення та використання відомих способів діяльності в новій ситуації, на готовність до пошуку розв'язання нових проблем, що виявами творчості.

Вивчення процесу становлення творчої особистості, здатної самостійно мислити і приймати відповідальні рішення, має наукову та практичну актуальність.

Різні науковці трактують по-різному можливість і правомірність навчання творчості. Одні автори вважають, що процес творчості неповторний, унікальний, що його неможливо зімітувати (А. Брушлинський). Інші (Г. Альтшуллер, І. Волков. В. Мерцалова, В. Розумовський, Ю. Саламатов, А. Уразова) дотримуються думки, що процес творчості цілком керований, що творчості необхідно і можна вчити. У роботах В. Андреєва, I. Лернера, О. Цибулі, Дж. Ніренберга, А. Шевирьова наголошується на можливості 
створення в навчальному процесі умов, що сприяють активізації творчої діяльності студентів.

Науковці у своїх працях зазначають, що тільки створення ситуацій щодо вияву творчості формує відповідну творчу діяльність. Питання розвитку творчих здібностей, творчого мислення розкривають у своїх працях В. Андреєв, В. Біблер, О. Богданова, В. Вергасов, Дж. Гилфорд, А. Жуганов, Г. Журавльов, В. Зелеєва, І. Лернер, К. Платонов, Б. Теплов та інші. Поняття «саморозвиток особистості» $є$ основним для характеристики цілей, змісту і засобів навчання і виховання у працях М. Бахтіна, Н. Бердяєва, О. Газмана, А. Маслоу, Н. Нікандрова, С. Смірнова, С. Шиянова, К. Ушинского та інших.

У роботах дослідників представлені різноманітні способи активізації творчої пізнавальної діяльності студентів:

- розв'язання творчих задач і проблемних ситуацій

(Т. Міракова, А. Орєхов, Дж. Пойа, А. Тряпіцина, Р. Хазанкін);

- складання задач (Т. Певчева, С. Страчевський, П. Ерднієв);

- створення або перетворення навчальних алгоритмів та програм (В. Голіков, Б. Гохват, Л.Ланда);

- виконання самостійних практичних робіт та самостійне засвоєння матеріалу (М. Вейт, Н. Віленкін, М. Гарунов, П. Підкасистий, В. Шаталов);

- застосування евристичного методу навчання (В.Андрєєв, Т. Певчева, Т. Таубаєв);

- використання дослідницького підходу в навчанні (В. Крутецький, І. Лернер, Н. Пручкіна, М. Скаткін).

Сучасні науковці стверджують, що творчість - найвищий щабель пізнавальної і практичної діяльності студентів. Мета творчої діяльності - не тільки подальше вдосконалення отриманих знань, але і всебічна активізація мислення студентів, розвиток їхніх пізнавальних здібностей. «Творчість - це будь-яка діяльність людини, яка створює щось нове, чи буде це створенням якої-небудь речі зовнішнього світу або побудова розуму чи почуття, яке живе в самій людині», - писав свого часу Л. Виготський.

Джерело розвитку студента - спеціально організоване навчання, у якому здійснюється творча діяльність за самостійним осмисленням, відкриттю для себе наукових закономірностей, законів, способів розв'язання завдань. Цьому всіляко сприяють навчальні підходи, що спонукають розумову активність, винахідливість, кмітливість, прагнення здобувати знання. Процес розвитку особистості студента в навчанні слід розглядати як процес творіння чогось нового для нього в пізнавальній та предметної діяльності. Результатом творчості у процесі навчанні є створений студентом творчий продукт. Розвиваючись як суб'єкт творчої діяльності, студент стає все більш вільним у виборі мети і способів його досягнення. Найвищих щаблів він досягає, коли головною цінністю для нього стає саморозвиток і він здатний рефлексивно ставиться до своєї діяльності.

Творча пізнавальна діяльність передбачає виявлення нових сторін досліджуваних явищ, розширення та поглиблення професійних знань. Студенти, які працюють творчо, не обмежуються підручником, а використовують інноваційні інтерактивні інформаційні технології. У процесі роботи вони знаходять питання, які потребують додаткового вивчення, і здійснюють, нехай і скромні, але самостійні дослідження.

Розв'язання задачі становлення творчої особистості залежить від вищої школи настільки, наскільки організований освітній процес, організатором якого $є$ викладач. Саме в нього повинні бути творчі підходи до навчального процесу, нові ідеї. Платонов писав, що посада «вчителя набагато вагоміша за найвищі посади в державі» [2, с. 241; 5, с. 450]. Як відомо, творчі викладачі відрізняються великими розумовими здібностями, бажанням експериментувати і накопичувати новий досвід. Зміст праці викладача тим багатший, чим багатша його праця у творчості [4]. Істотно змінюється і підвищується ефективність викладання професійно спрямованих дисциплін за рахунок упровадження й апробування інтерактивних інформаційних технологій. Для ефективності творчого акту потрібно 
тривале накопичення досвіду, який консолідується в уміннях, знаннях i навичках викладання, осмисленні майбутньої роботи.

Будь-яка творчість потребує знань, умінь та навичок. На нашу думку, самих їх не достатньо, вони лише надають можливість добувати нові ідеї, нові думки, нові підходи та рішення. Здійснювати це викладач може під час практичної діяльності за допомогою інформаційних технологій. I саме практика здатна показати, наскільки ефективна діяльність викладача.

У навчанні спеціалістів інженерних спеціальностей у сучасній вищій школі діяльність викладача має на меті допомогти студентам в оволодінні ефективними методами й засобами, а також допомогти майбутнім фахівцям підвищити загальний рівень, який відповідав би запитам сучасного суспільства. Викладач прагне досягти цих цілей шляхом підвищення рівня навчання 3 опорою на інтерактивні інформаційні технології.

Отже, виходячи з вище зазначеного, можна зробити висновок, що в навчальному процесі творчість викладача відіграє важливу роль 3 використанням інформаційних технологій. Але не менш важливим складником цього процесу $\epsilon$ творчий потенціал студента.

Творчий потенціал це складна особистісно-діяльністна характеристика особистості, що відображає сукупність особистісних якостей і здібностей, психологічних станів, знань, умінь і навичок, необхідних для здійснення особистістю творчої діяльності та досягнення високого рівня розвитку, завдяки актуалізації своїх творчих сил і можливостей у реальній практиці. Творчий потенціал студента стане продуктивною силою тільки тоді, коли внутрішні спонукання корелюватимуть із об'єктивними задачами, які ставить перед ним викладач. Розвивати творчий потенціал студентів можна за допомогою теоретичних занять (лекції, бесіди, дискусії), семінарських та практичних занять із використанням інтерактивних інформаційних технологій, які передбачають виконання творчих робіт, рольових ігор, індивідуальних, творчих завдань тощо.

Студент повинен прагнути до розкриття творчого особистісного потенціалу, i викладачу потрібно йому допомогти в цьому процесі. Перш за все шляхом забезпечення творчої атмосфери, доброзичливості, формуванням почуття радості від досягнутого, стимулюванням творчої активності. По-друге, формування творчого ставлення студентів до навчання має відбуватися із застосуванням сучасних комп’ютерних технологій, які $є$ невід'ємною частиною життя сучасної молоді. Тому розвинути закладений у кожній особистості творчий потенціал - значить, допомагати запровадженню й реалізації в навчальному процесі сучасних інноваційних інформаційних технологій у предметноорієнтовному комп'ютерному середовищі. На нашу думку, саме інтерактивні інформаційні технології надають студентам потужні засоби для отримання доступу до інформаційних ресурсів, співробітництва 3 іншими людьми, консультацій, обміну знаннями і розв'язання складних професійних проблем.

Сучасні комп'ютерні засоби дозволяють у рамках однієї програми інтегрувати тексти, графіку, звук, анімацію, відеокліпи, високоякісні фотозображення. Саме поняття комп’ютерне середовище також потребує конкретизації і більш чіткого визначення. Програмний продукт, заснований на інтегруванні комп’ютерних технологій у процес навчання, повинен бути перш за все інструментом освітнього процесу, причому він повинен бути інструментом як для студента, так і для викладача. Такий інструмент не повинен обмежувати намірів користувачів, нав'язувати їм жорстко задану послідовність операцій у процесі навчання. Контроль системи за діями користувача мінімальний, ці дії можуть бути легко відтворювані і повинні природно трансформуватися в результати процесу навчання. Виконання цих вимог робить комп'ютерну систему активним середовищем, найбільш повно реалізує переваги «спілкування» людини 3 комп'ютером. Навчаючись і навчаючи в такому активному середовищі, користувач сам наповнює іiі специфічними об'єктами своєї предметної області, вивчає їх властивості і створює на цій 
основі відповідні інформаційні моделі. На основі цих моделей відбувається формування і закріплення корисних для вирішення конкретних завдань навичок, які i визначають ступінь володіння інформацією досліджуваної області. Така стратегія навчання найбільш повно відповідає сучасній концепції навчання вищої освіти. Предметно-орієнтоване комп'ютерне середовище набагато полегшує реалізацію методів і засобів навчання 3 використанням поетапного формування розумових дій, що підвищує ефективність навчального процесу, формує уміння самостійно приймати рішення, знаходити спосіб ії розв'язання, а також сприяє творчому підходу до оволодівання професійними навичками.

Творчому підходу викладача та студентів до навчання у предметно-орієнтованому комп'ютерному середовищі сприяє метод ігрового моделювання у вигляді системи професійно спрямованих навчально-рольових ігор, а також ситуацій, епізодів із проблемами реальної дійсності як опосередкованих фрагментів майбутніх навчальнорольових ігор. Навчально-рольові ігри виконують функції стратегії розвитку професіоналізму фахівців інженерного профілю як своєрідного полігону, на якому майбутні спеціалісти можуть перевіряти різні схеми поведінки, поведінкові зразки комунікації. Справжня гра - це завжди глибоко осмислена діяльність спонтанного прогнозу - виконання результатів майбутньої діяльності. Навчально-рольова гра професійної спрямованості - це не проста діяльність, не вигадки і фантазії, а цілком реальний вхід до суміжного майбутнього.

Перспективним напрямком у вивченні екології $\epsilon$ краєзнавчий підхід із використанням технології Google Планета Земля (англ. Google Earth) [3]. Це проект компанії Google, у межах якого в мережі Інтернет розміщено супутникові фотографії всієї земної поверхні. Використання проекту доцільно як для вивчення екосистем, так і як фундамент створюваних ігрових програм. Нині програма-ресурс Google Earth («віртуальний глобус») і спрощений 3D-редактор SketchUp становлять складники системи програмних продуктів, так що користувач може легко переносити інформацію з одного пакету в інший. Відповідно, i ці програми, i, що особливо важливо, їх синхронізація, залучення громадськості до наповнення інформацією, є абсолютно унікальним, не має аналогів.

У синхронізації додатків $є$ і альтруїстичний аспект: будь-який бажаючий може самостійно збагатити додаток Google Earth побудованими моделями вже наявних будівель.

Розглянуті вище програмні технології покладено в основу ігрового проекту «ЕкоКривбас», який розроблено і впроваджено у навчальний процес ДВНЗ «Криворізький національний університет». Серед багатьох інших рольовій грі «ЕкоКривбас» відведено відповідне і навіть унікальне місце. Воно пов'язане переважно з осмисленням, наочним моделюванням відтворення процесів виникнення і розв'язання кризових явищ і конфліктів щодо екологічного стану на Криворіжжі.

Заняття 3 ігровою методики навчання (дослідні, інструментально-змагальні, навчально-рольові ігри) відрізняються від традиційних своїм нестандартним змістом, емоційністю, інноваційними прийомами, високою результативністю, строкатим розмаїттям ігрових моделей. 3 упевненістю можна сказати, що у зв'язку з бурхливим прогресом в області розроблення комп'ютерних методів і засобів, створенням глобальних інформаційних мереж (Internet), зазначені вище інтерактивні підходи в навчанні будуть відігравати головну роль у розвитку творчого інженерного мислення.

Рішення задачі розвитку творчої особистості майбутнього інженера залежить від вищої школи настільки, наскільки організовано освітній процес, головною фігурою якого $\epsilon$ викладач. Саме в нього повинні бути творчі підходи до навчального процесу, нові ідеї. Завдяки творчій атмосфері в навчальному процесі у студентів формується творче ставлення до навчання. Результатом творчого процесу в навчанні є створений студентом творчий продукт. Формуванню творчого підходу в навчальному процесі сприяють інтерактивні інформаційні технології. 


\section{Література}

1. Андреев В. И. Диалектика воспитания и самовоспитания творческой личности / В. И. Андреев. - Казань : Изд-во КГУ, 1988. - 240 с. 2. Артемьева О. А. Система учебно-ролевых игр профессиональной направленности : [монография] / О. А. Артемьева, М. Н. Макеева. - Тамбов : Изд-во Тамб. гос. техн. ун-та, 2007. - 208 с. 3. Википедия с описанием Google Earth. [Електронный ресурс] / Википедия. Режим доступа: http://ru.wikipedia.org/wiki/GoogleEarth. 4. Володарская Е. Б. Творчество как неотъемлемое требование к профессиональной компетентности преподавателя иностранных языков / Е. Б. Володарская, М. М. Степанова // Инновационные компетенции и креативность в исследовании и преподавании языков и культур : [сборник статей по материалам II Всероссийской (с международным участием) научнопрактической конференции, 20 ноября 2009 г., г. Москва]. - М. : РГСУ, 2009. - С. 124-127. 5. Лернер И. Я. Дидактические основы методов обучения / И. Я. Лернер. -М. : Педагогика, - 1981. 116с. 6. Эльконин Д. Б. Психология игры / Д. Б. Эльконин. - 2-е изд. - М. : Гуманитарный изд. центр «Владос», 1999. - 360 с.

УДК 372.018

C. M. Ibax,

кандидат пед. наук, доиент, Дрогобицький державний педагогічний університет імені Івана Франка

\section{ОСОБЛИВОСТІ ПЕДАГОГІЗАЦІЇ БАТЬКІВ ДІТЕЙ ДОШКІЛЬНОГО ВІКУ}

Івах С. М. Особливості педагогізації батьків дітей дошкільного віку.

У статті акцентовано на важливості тісного взаємозв'язку сім'ї та дошкільного навчального закладу задля створення для кожної дитини єдиного, дитиноцентричного виховного середовища; виокремлено основні засади їх взаємодії; обгрунтовано ефективні форми та методи їхньої співпраці.

Ключові слова: дошкільний навчальний заклад, сім'я, педагогізація батьків, взаємодія, співробітництво, партнерство.

Ивах С. М. Особенности педагогизации родителей детей дошкольного возраста.

В статье акцентируется на важности тесной взаимосвязи семьи и дошкольного учебного учреждения для создания каждому ребенку единой, детоцентричной воспитательной среды; выделяются основные засады их сотрудничества; обосновываются эффективные формы и методы их сотрудничества.

Ключевые слова: дошкольное учебное учреждение, семья, педагогизация родителей, взаимодействие, сотрудничество, партнерство.

Ivakh S. The features of parents' pedagogisation of preschool children.

The article emphasizes the importance of the close relationship of the family and kindergarten to create one for each childsentrystic educational environment. It also singles out the basic principles of their interaction and substantiates effective forms and methods of their collaboration.

Key words: pre-school, family, parents' pedagogisation, interaction, collaboration, partnership.

Ідея взаємозв'язку суспільного й сімейного виховання знайшла своє відображення в низці нормативно-правових документів нашої держави: Концепції дошкільного виховання в Україні, Державній національній програмі «Освіта. Україна XXI ст.», Законі України «Про дошкільну освіту», «Базовому компоненті дошкільної освіти в Україні» та Базовій програмі розвитку дитини дошкільного віку «Я у Світі» та ін. У них декларуються зміни щодо позиції дошкільного закладу в роботі з сім'єю.

Так, у Базовій програмі «Я у Світі» зазначено, що модернізація дошкільної освіти не може не торкнутися сучасної сім'ї, лишити родину стороннім спостерігачем змін, що відбуваються у першій іiі ланці, не обмежувати іiі інтересів. Відповідно до цього кожен дошкільний навчальний заклад не тільки виховує дітей, а й консультує батьків 3 питань їхнього виховання. Надання батькам допомоги в актуальних виховних питаннях сприяє 